\author{
Zbigniew Zioło \\ Uniwersytet Pedagogiczny \\ im. Komisji Edukacji Narodowej \\ w Krakowie
}

\title{
Miejsce przedsiębiorczości w edukacji
}

W kształtowaniu się gospodarki rynkowej oraz nasilających się procesach globalizacji i związanych z nimi procesach integracji europejskiej szczególnie ważnym problemem jest przygotowanie każdego człowieka i całego społeczeństwa do umiejętnego zachowania się w zmieniających się uwarunkowaniach gospodarczych, społecznych, kulturowych i politycznych. Zmiany te wynikają z szybkiego postępu naukowo-technologicznego i technicznego, tendencji do umiędzynarodawiania działalności gospodarczej, zmian w systemach organizacji, zarządzania i in. Szczególnie ważną rolę w tym zakresie odgrywa edukacja prowadzona na wszystkich poziomach kształcenia, dokształcania i doskonalenia zawodowego, podporządkowana kształtowaniu aktywnych postaw człowieka w zmieniających się strukturach regionalnych, krajowych, a także na obszarze poszczególnych kontynentów i w przestrzeni światowej. Poznanie zmieniających się uwarunkowań i reguł rozwoju społeczno-gospodarczego i kulturowego jest niezbędne dla rozwijania racjonalnych powiązań naukowo-technologicznych, produkcyjno-rynkowych, kapitałowo-finansowych i organizacyjnych między podmiotami gospodarczymi, instytucjami a społeczeństwami funkcjonującymi w przestrzeni regionalnej, krajowej, europejskiej i światowej.

Podejmując problematykę dotyczącą określenia miejsca przedsiębiorczości w szeroko pojmowanej edukacji, nawiązujemy do wcześniejszych osiągnięć badawczych dotyczących: roli przedsiębiorczości wobec współczesnych wyzwań cywilizacyjnych, podnoszenia konkurencyjności społeczeństwa i gospodarki, wpływu przedsiębiorczości na wzrost aktywności gospodarowania, kreowania gospodarki opartej na wiedzy i kształtowania społeczeństwa informacyjnego, a także określenia roli przedsiębiorczości w nasilających się warunkach integracji europejskiej i globalizacji (Zioło, Rachwał 2005; 2006; 2007; 2008; 2009; 2010; 2011). W literaturze przedmiotu znajdują się pozycje autorów podejmujących bardziej szczegółowe problemy badawcze, dotyczące:

- określania celów edukacji przedsiębiorczości (Dorocki, Kilar, Rachwał 2011; Rachwał, Kudełko, Tracz, Wach, Kilar 2008; Rachwał 2009),

- treści przedmiotowych przedsiębiorczości (Kilar 2007; 2009; Piróg 2005; Rosiak, Szczypa 2007; Wąsik 2010),

- dydaktyki nauczania przedsiębiorczości (Desperak 2007; Tracz, Rachwał 2008),

- kształcenia postaw przedsiębiorczych w edukacji szkolnej (Błażejewski 2006, Makieła 2005, Rachwał 2005),

- treści przedsiębiorczości w wybranych przedmiotach szkolnych (Borowiec, Rachwał 2011; Tracz 2006; Kawecki 2005), 
- zachowania młodzieży na rynku pracy (Czapliński 2006; Mitura, Jamróz 2005; Sowislok 2007; Zachariasz 2011; Zioło 1999),

- kształcenia przedsiębiorczości na poziomie akademickim (Borowiec 2008; 2009; 2011; Piróg 2010; Zioło 1984) oraz

- roli przedsiębiorczości w rozwoju gospodarczym i społecznym (Gierańczyk 2009; Grodzicki 2000; Majewska 2006).

W niniejszych rozważaniach wychodzimy z założenia, że kształtowanie postaw przedsiębiorczych, przejawiających się w dążeniu do rozwijania aktywności gospodarczej, społecznej, kulturowej czy politycznej, jest niezbędne na wszystkich szczeblach edukacji instytucjonalnej, począwszy od poziomu wczesnoszkolnego poprzez poziom podstawowy, gimnazjalny, ponadgimnazjalny do kształcenia na poziomie akademickim, a następnie w procesie dokształcania i doskonalenia zawodowego w całym okresie aktywności człowieka na rynku pracy i działalności społecznej. Przyjmujemy, że proces ten winien być wspierany przez różnorodne podmioty gospodarcze i instytucje funkcjonujące w otoczeniu społeczno-gospodarczym i kulturowym każdego człowieka.

W świetle zarysowanych przesłanek w poniższych rozważaniach podejmujemy problematykę kształtowania postaw przedsiębiorczych w szeroko pojętej działalności edukacyjnej. Szczególna uwaga zostanie zwrócona na możliwości kształtowania się postaw przedsiębiorczych w procesie dydaktycznym oraz oczekiwania przedsiębiorstw w stosunku do pracowników.

W procesie edukacyjnym ważną rolę odgrywa dążenie do coraz precyzyjniejszego poznania i rozumienia reguł ekonomicznego rozwoju, dzięki którym społeczeństwo w sposób efektywny wypracowuje określone środki, które następnie mogą być odpowiednio podzielone. Należy dążyć do przyswojenia przez młodego człowieka podstawowej zasady, że zarówno potrzeby każdej osoby, jak i społeczeństwa są nieograniczone, ale możliwości ich zaspokojenia są ograniczone przez wartość wypracowanych zasobów finansowo-kapitałowych ${ }^{1}$. Wielkość wygospodarowanych środków w podstawowym stopniu zależy od efektywności działalności gospodarczej, którą osiąga się dzięki zwiększonej wydajności pracy, przez wdrażanie nowoczesnych technologii, przygotowanie odpowiednio wykształconej kadry pracowniczej, a także stosowanie bardziej racjonalnych metod organizacji i zarządzania. Istotną funkcję w tym zakresie pełnią przyjmowane kierunki polityki zakładające określone cele rozwoju społecznego, gospodarczego i kulturowego, które mogą być realizowane w konkretnych uwarunkowaniach otoczenia międzynarodowego, europejskiego, krajowego, regionalnego czy lokalnego. Każda działalność gospodarcza, społeczna i kulturowa jest prowadzona na określonym rynku, na którym zachodzą odpowiednie relacje między oferowanym przez niego produktami (wyrobami, usługami, pracą) a potencjalnymi odbiorcami, dysponującymi określonymi zasobami finansowymi. Działalność ta związana jest z podejmowaniem samodzielnych decyzji, które wynikają z chęci osiągnięcia określonych korzyści materialnych czy pozamaterialnych, jak również wiążą się z określonym ryzykiem. Odnosi się to nie tylko do działalności człowieka w sektorach produkcyjnych, usługowych i instytucjach, ale także do działalności gospodarczej, społecznej, kulturowej czy w zarządzaniu gospodarstwem domowym.

\footnotetext{
${ }^{1}$ Można przyjąć, że nieprzestrzeganie tej zasady doprowadziło do zadłużenia gospodarek wielu krajów. W 2011 roku łączne zadłużenie rządów na świecie wynosiło 33 bln euro, a najbardziej zadłużonymi krajami były: Stany Zjednoczone (11,5 bln), Japonia (9,1 bln) Niemcy (1,8 bln), Francja (1,6 bln), Wielka Brytania (1,6 bln), Włochy (1,6 bln) i Brazylia (1,0 bln). Główną przyczyną tego zadłużenia jest zbyt rozbudowany system świadczeń społecznych (por. Adamczyk, Fandrejewska 2012).
} 


\section{Przesłanki ksztaltowania postaw przedsiębiorczych}

Procesy rozwoju społecznego, gospodarczego i kulturowego bardzo ściśle związane są z bazą ekonomiczną, której poziom i jakość wyznaczają określone fazy rozwoju cywilizacyjnego (feudalna, industrialna postindustrialna, informacyjna). Zmieniające się formacje społeczno-ekonomiczne i kulturowe, a także zróżnicowany poziom rozwoju krajów czy regionów wymagają z reguły odmiennych umiejętności, składających się na preferowany ideał człowieka. W zależności od fazy rozwoju obowiązujące zasady stawiają jednostkom różne wymagania, na przykład w średniowieczu propagowany był typ osobowości rycerskiej i związany z tym „ideał rycerza, który lubuje się w bitwach, turniejach i wyprawach wojennych" (Szczepański 1973, s. 47). Współcześnie preferowana jest osobowość człowieka innowacyjnego o postawie przedsiębiorczej, który potrafi rozwijać swoją działalność na polu gospodarki, edukacji, badań naukowych czy kultury. Postawa ta pozwala na podnoszenie jakości i poziomu życia, a poprzez udział we władzach, może wpływać na zwiększanie intensywności rozwoju różnej skali układów przestrzennych. Współczesne procesy rozwoju wpływają na kształtowanie nowej jakościowo bazy ekonomicznej, nawiązującej do społeczeństwa informacyjnego. Poznanie tych złożonych procesów oraz przygotowanie do nich poszczególnych osób i społeczeństwa należy do kluczowych zadań zarówno edukacji, praktyki gospodarczej, administracji rządowej i samorządowej, jak i instytucji pozarządowych.

Współczesny zróżnicowany poziom rozwoju krajów i regionów jest wynikiem działania często odmiennych czynników oraz uwarunkowań wewnętrznych i zewnętrznych, czego wyrazem może być zróżnicowana wartość PKB przypadająca na jednego mieszkańca ${ }^{2}$. Dlatego bardzo ważnym zadaniem elit politycznych i społecznych jest dążenie do poznania i ciągłego dynamizowania procesów rozwojowych, celem osiągania coraz wyższego poziomu rozwoju. Podstawowym warunkiem osiągnięcia sukcesu ekonomicznego, społecznego, kulturowego i politycznego jest przemyślane, zorganizowane kształcenie oraz zaufanie do ludzkiej przedsiębiorczości i innowacyjności, którą należy traktować jako stan umysłów i związanych z nim postaw. Podkreślanie konieczności korzystania i dostępu do rozwiniętych technologii nie wystarczy, aby gospodarkę określić jako innowacyjną. Gospodarkę innowacyjną mogą kreować tylko wykształceni i odpowiednio przygotowani pracownicy mający wpojone nawyki myślenia innowacyjnego i umiejętności wdrażania nowych rozwiązań w produkcji, usługach, pracach naukowych, badawczych, technologicznych, technicznych oraz w zakresie organizacji i zarządzania.

Dla wdrażania nowoczesnych procesów rozwoju gospodarczego, społecznego i kulturowego kraju czy regionu konieczne są więc jasne cele, które pozwolą na przyspieszenie wzrostu i skracania dystansu cywilizacyjnego w stosunku do krajów ekonomicznie rozwiniętych. Biorąc pod uwagę ograniczony potencjał społeczno-ekonomiczny i kulturowy, konieczne jest wyznaczenie

\footnotetext{
${ }^{2}$ W 2008 roku wśród krajów europejskich wartość PKB na mieszkańca wahała się od 105,1 tys. dol. w Luksemburgu, 79,0 tys. w Norwegii i 56,1 tys. w Danii do 6,2 tys. w Białorusi i 3,9 tys. w Ukrainie. W dominujących krajach Unii Europejskiej wynosiła ona: we Francji - 41,1 tys., w Niemczech 40,7 tys., Wielkiej Brytanii - 35,2 tys. i we Włoszech $-35,1$ tys., a w Polsce $-11,3$ tys. Zob. Główny Urząd Statystyczny 2011, s. 950.
} 
odpowiednich celów strategicznego rozwoju nawiązujących do współczesnych kierunków rozwoju cywilizacyjnego, wytypowanie kluczowych sektorów gospodarki oraz upowszechnienie i podnoszenie poziomu i jakości edukacji. Nawet najlepiej przygotowane strategie zmian strukturalnych skopiowane z krajów i regionów ekonomicznie rozwiniętych nie przyniosą spodziewanego efektu, jeżeli nie wykształcimy ludzi, którzy będą rozumieli ich sens, potrafili je rozwijać, nimi sterować oraz efektywnie wykorzystywać w krajowych czy regionalnych uwarunkowaniach. Fundamentem takiego rozwoju jest odpowiednia edukacja, której treści kształcenia, dokształcania, a także doskonalenia będą nawiązywać do współczesnych wyzwań cywilizacyjnych.

Poznawanie w okresie edukacji szkolnej czy akademickiej mechanizmów kształtowania procesów gospodarczych, społecznych, kulturowych i politycznych jest ważne, ponieważ w tym okresie następuje najbardziej dynamiczny rozwój osobowy, umysłowy i fizyczny, kształtowanie odpowiednich postaw moralno-etycznych, a także uzmysławianie odpowiedzialności za podejmowane decyzje i ich konsekwencje w przyszłości. Ważnym problemem pozostaje więc to, jak młodzież będzie przygotowana do funkcjonowania w szeroko rozumianych strukturach społecznych, zmieniającego się gospodarstwa domowego, przedsiębiorstwa, instytucji, a także gminy, regionu, kraju, Europy czy świata.

Proces kształtowania młodego człowieka jest bardzo złożony i dokonuje się poprzez różnorodne źródła informacji, z których do ucznia czy studenta dociera wiedza, treści ideologiczne, wartości kultury duchowej, preferowane wzorce zachowań, przykłady postępowania oraz zasady życia osobistego, współżycia rodzinnego i społecznego. Podstawową rolę tym zakresie odgrywają (Szczepański 1973):

- rodzina,

- system edukacyjny,

- wzorce uznawane przez środowiska kolegów i znajomych,

- organizacje młodzieżowe,

- zakłady pracy,

- środki masowego przekazu,

- instytucje upowszechniania wiedzy, dokształcania i doskonalenia zawodowego,

- instytucje upowszechniania kultury, w tym: kino, teatr, muzea, instytucje sportowe oraz turystyczne,

- instytucje państwowe (w tym wymiaru sprawiedliwości), które regulują sprawy życia obywateli i zaspakajania ich potrzeb.

\section{Możliwości ksztaltowania postaw przedsiębiorczości w procesie edukacyjnym}

Proces edukacyjny ma znaczący wpływ na kształtowanie podstaw przedsiębiorczych młodzieży. Poszczególne przedmioty humanistyczne, przyrodnicze, matematyczno-fizyczne, światopoglądowe czy ekonomiczne mogą promować przedsiębiorcze zachowania młodzieży w różnym stopniu. Poniżej zostanie jedynie podjęta próba zarysowania tej złożonej problematyki, która winna być rozwijana w dalszych pracach, zwłaszcza przy budowaniu programów edukacyjnych, opracowaniach podręczników i pomocy dydaktycznych (ryc. 1). 


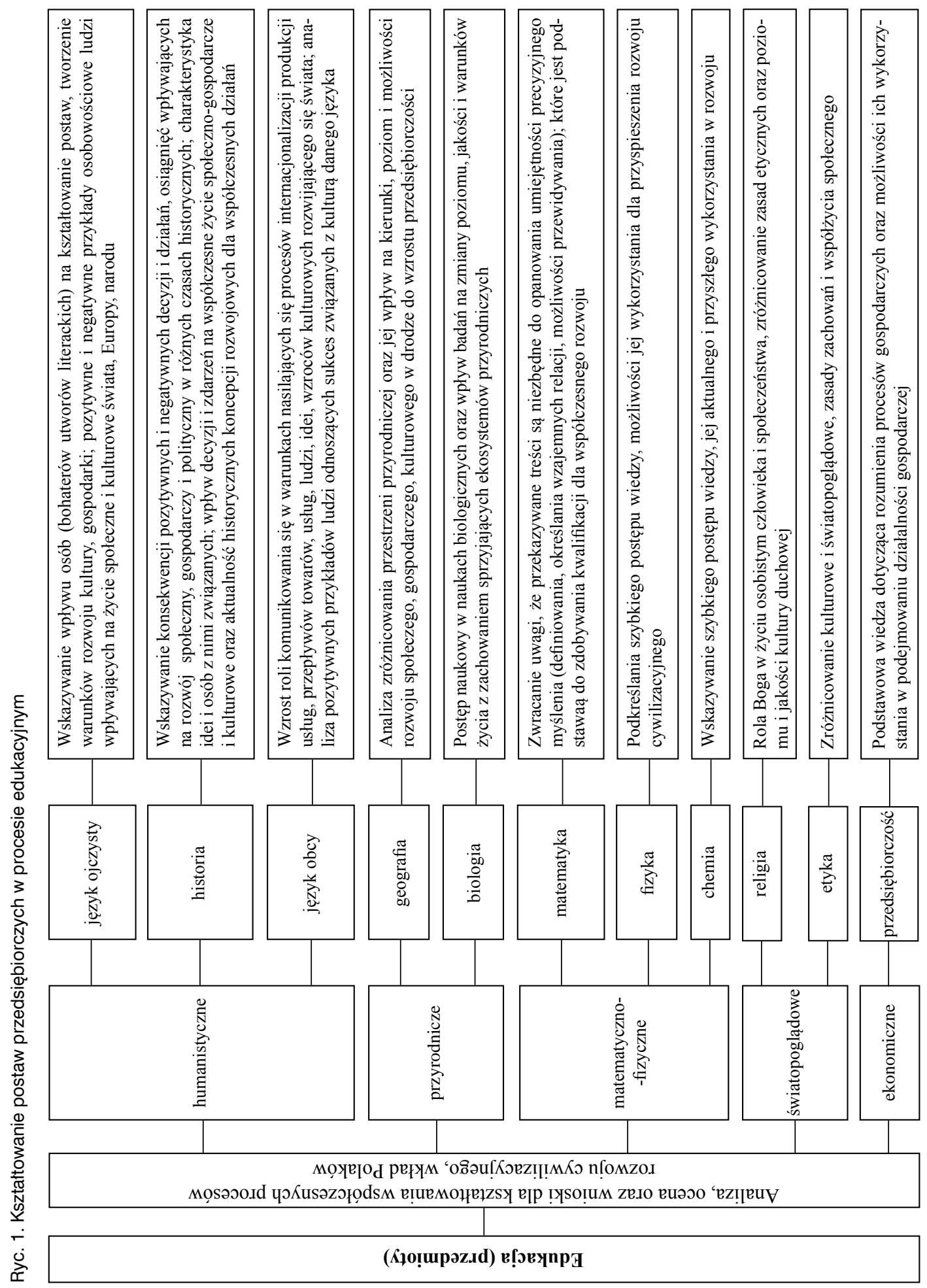

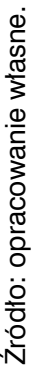


Jak wynika z ryciny 1, postawy przedsiębiorcze można kształtować w procesie nauczania wszystkich przedmiotów szkolnych, ponieważ w zakresie każdego przedmiotu znajduje się wiele odpowiednich do tego treści merytorycznych. W treściach edukacyjnych obejmujących poznawanie przeszłych, współczesnych i przyszłych procesów rozwoju cywilizacyjnego powinno się też w większym stopniu podkreślać wkład Polaków w rozwój: naukowy, techniczny, ekonomiczny, organizacyjny, społeczny i kulturowy świata, Europy, kraju czy regionu ${ }^{3}$. Podobne praktyki stosuje się w innych krajach, gdyż pozytywne przykłady mogą stanowić interesujące wzorce dla młodych ludzi, przyczyniać się do podnoszenia ich aspiracji i planów życiowych oraz wzbudzać poczucie dumy z polskich osiągnięć.

Kształtowanie młodego człowieka przez treści poszczególnych podmiotów może prowadzić do rozwijania lub ograniczania jego aspiracji. Preferowane pozytywne wzorce pozwolą mu na rozwijanie aspiracji i kształtowania racjonalnych planów życiowych, nawiązujących do potrzeb rynku pracy czy możliwości samodzielnego podejmowania działalności gospodarczej. Stanowi to ważną przesłankę do właściwego wykorzystania własnej wiedzy, zdolności i zamiłowań, co w konsekwencji prowadzić będzie do stopniowego osiągania coraz poważniejszych sukcesów życiowych i zawodowych. Niewłaściwie analizowane treści poszczególnych przedmiotów mogą również obniżać aspiracje młodego człowieka oraz ograniczać możliwości wykorzystania jego wartości intelektualnych, np. poprzez prezentowanie negatywnych wzorców zachowań. W konsekwencji mogą one ograniczać chęci budowania ambitniejszych planów życiowych, co z reguły prowadzi do rezygnacji z chęci stawiania sobie ambitniejszych celów życiowych (Turczyn-Zioło 1979).

W kreowaniu przedsiębiorczego człowieka ważną rolę odgrywa więc poznanie jego predyspozycji i uzdolnień oraz stwarzanie możliwości rozwijania ich podczas zajęć dydaktycznych czy indywidualnej pracy w kołach zainteresowań na terenie szkoły, w środowisku lokalnym lub domowym. Szczególne znaczenie ma stwarzanie sytuacji, w których młody człowiek może poznawać siebie, podejmować trud świadomego poszukiwania swojego przyszłego miejsca w zmieniających się strukturach społecznych i zawodowych. W wyborze tym nie bez znaczenia jest na przykład zróżnicowanie płac czy przywilejów pracowniczych, a także potrzeb na lokalnym, regionalnym, krajowym czy międzynarodowym rynku pracy, które należy uwzględniać, kształtując odpowiedni stosunek do różnych kategorii zawodów. Ważne w tym zakresie jest również wykształcenie umiejętności do adaptacji w różnych środowiskach oraz ciągłego dokształcania się i samodoskonalenia (Szczepański 1973).

\footnotetext{
3 Przykładowo w publicystyce i literaturze przedmiotu wielu autorów, analizując różnice kulturowe, powołuje się na pracę S.P. Huntingtona z 1996 roku The Clash of Civilizations and the Remaking of World Order (Zderzenie cywilizacji - wydanie polskie z 2008 roku), podczas gdy na problematykę tę zwrócił uwagę F. Koneczny w pracy z 1935 roku. W wyniku zaniedbań badawczych i pomówień zupełnie usunięto z pamięci prof. Jana Czochralskiego, który m.in. wymyślił sposób hodowania dużych kryształów metali, a rehabilitowano go dopiero po 66 latach (Cieśliński 2011; Rybak 2011). Czy w należytym stopniu prezentowane są osiągnięcia polskich uczniów i studentów? Polscy studenci w ubiegłorocznych zawodach robotów mobilnych w Europie - RobotChallange - organizowanych w Wiedniu, a uznawanych za najbardziej prestiżowe w Europie, zajęli pierwsze miejsce. W sumie w zawodach pokazano 300 konstrukcji, które zostały zaprezentowane przez studentów z 17 krajów. W klasyfikacji medalowej pierwszą pozycję zajęli polscy studenci, którzy zdobyli 6 złotych medali, 4 srebrne i 4 brązowe. Drugą pozycję zajęli studenci słowaccy ( 2 medale złote, 1 srebrny i 1 brązowy), a następnie studenci z: Austrii, Litwy, Hiszpanii. Szwecji, Niemiec, Turcji, Rumunii, Łotwy i Czech (zob. Robot studentów z AGH bezkonkurencyjny 2011). Polscy uczniowie z Torunia i Sierpca odkryli dwie nieznane wcześniej planetoidy (zob. Polscy uczniowie 2011; Polskie łaziki podbijaja Marsa 2011).
} 
Kształtowanie postaw przedsiębiorczych jest niezbędne nie tylko dla przyszłych ekonomistów czy przedstawicieli zawodów technicznych, ale także dla ogółu społeczeństwa niezależnie od kierunków kształcenia i zdobywanych kwalifikacji zawodowych ${ }^{4}$. Postawy te są też niezbędne w prowadzeniu własnego gospodarstwa domowego, indywidualnej działalności gospodarczej czy artystycznej. Wszędzie musimy podejmować decyzje na podstawie reguł efektywności ekonomicznej, które pozwalają na zdobywanie środków finansowych i kapitałowych, ich wykorzystanie oraz racjonalną alokację wyników działalności (zysków).

\section{Oczekiwania rynków pracy}

W procesie rozwoju gospodarczego, społecznego i kulturowego ważnym problemem są zmieniające się oczekiwania rynku pracy, do którego przygotowuje się absolwentów poszczególnych kierunków kształcenia. Wraz z wprowadzaniem nowych osiągnięć technologicznych i technicznych, zmieniają się nie tylko systemy organizacji i zarządzania produkcją i usługami, ale także następuje zmiana działalności różnego typu instytucji i organizacji. W konsekwencji zmieniają się reguły kształtowania kapitału ludzkiego przejawiające się między innymi w oczekiwaniach przedsiębiorstw w stosunku do potencjalnych pracowników. Obok wymagań wiedzy merytorycznej i związanych z nią umiejętności zawodowych, przedsiębiorstwa oczekują wysokiego poziomu etycznego. Wskazują na to badania Instytutu Badań nad Demokracją i Przedsiębiorstwem Prywatnym Krajowej Izby Gospodarczej, mające na celu odpowiedzieć na pytanie, jakie cechy i umiejętności decydują o użyteczności nowo przyjmowanych pracowników oraz w jakim stopniu cechy te są kształtowane przez szkoły wyższe (Zachariasz 2011). W badanych firmach najwyżej oceniano uczciwość, lojalność i odpowiedzialność przyszłego pracownika (tab. 1)5. Cechom tym przedsiębiorstwa przypisują największą wagę, dając najwyższą liczbę punktów (72 pkt.), a następnie doceniają odpowiedzialność, szacunek dla innych, dzielenie się wiedzą i elastyczność czasową (62-68 pkt.), natomiast najniższą wagę przywiązują do umiejętność konkurowania innymi (25 pkt.). Oceniając szkoły wyższe, przedsiębiorstwa uważają, że największy nacisk kładą one na umiejętność podejmowania nowych zadań i koleżeńskość (po 45 pkt.) oraz umiejętność konkurowania z innymi (43 pkt.). W znacznie mniejszym stopniu zwracają uwagę na dzielenie się wiedzą (26 pkt.), lojalność wobec firmy (27 pkt.) i otwartość na problemy innych (28 pkt.). Porównując oceny poszczególnych cech dokonane z punktu widzenia potrzeb przedsiębiorstwa i ich realizację przez szkoły wyższe, widać pewne rozbieżności. Największe różnice zaznaczają się w ocenie lojalności wobec firmy (45 pkt.), a następnie w zakresie elastyczności czasowej, uczciwości i szacunku dla innych (36 pkt.). Natomiast na zbliżonym poziomie oceniana była koleżeńskość, mobilność i gotowość podejmowania się nowych zadań. Pracodawcy poszukują osób, które: potrafią słuchać, rozumieją, co się do nich mówi, potrafią się jasno wypowiadać, współpracować w grupie oraz akceptują polecenia przełożonego.

Przedsiębiorstwa zwracają uwagę na fakt, że absolwenci nie potrafią krytycznie myśleć, nie dostrzegają potencjalnych szans, łatwo się poddają i rezygnują z swoich pomysłów. Szczególne słabo wśród absolwentów oceniają: braki w umiejętności pracy zespołowej i rozwiązywania

\footnotetext{
${ }^{4} \mathrm{Na}$ brak współzależności między obecnymi kierunkami kształcenia a potencjalnymi rynkami pracy wskazuje wielu autorów. W konsekwencji podejmowane są środki mające zachęcić uczniów do wybierania studiów technicznych, gwarantujących zatrudnienie (Suchy 2011; Czeladko 2011b). Licealiści w planach dalszej edukacji preferują nauki humanistyczno-społeczne - $23 \%$, nauki ścisłe $-20 \%$, medyczne -18 , ekonomiczne $-8 \%$ i sportowe $-4 \%$ (Czeladko 2011a).

${ }^{5}$ Badane firmy bardzo potrzebną cechę oceniały na 4 pkt., natomiast cechę zbędną na 0 pkt.
} 
problemów, a także komunikowania się. Pracodawcy szukają osób, które potrafią współpracować w grupie i nawiązywać kontakty interpersonalne. Ich zdaniem współczesny system edukacji jest nastawiony w znacznym stopniu na rywalizację.

Przedsiębiorstwa wysoko oceniały umiejętności absolwentów związane z uczeniem się i stosowaniem nowych technologii, a także chęcią zdobywania nowej wiedzy. Obok wiedzy i umiejętności wynikającej z przedmiotów technicznych i ekonomicznych, przedsiębiorstwa oczekują też od potencjalnych pracowników wiedzy z zakresu przedmiotów humanistycznych i światopoglądowych, które kształtują oczekiwane w pracy zawodowej cechy etyczno-moralne.

Preferowane przez przedsiębiorstwa cechy nie zawsze są korzystne dla młodego pracownika. Młody człowiek wśród ofert na rynku pracy szuka dla siebie takiej firmy, która daje mu: najwyższe dochody, najlepsze szanse podnoszenia kwalifikacji, doskonalenia i awansu zawodowego. W konsekwencji, po osiągnięciu górnych pułapów zarobków i braku dalszych możliwości podnoszenia kwalifikacji oraz braku możliwości osiągnięcia wyższego stanowiska i ograniczenia awansu zawodowego, pracownik zwykle nastawiony jest na zmianę miejsca pracy. Taki pracownik w mniejszym stopniu odpowiada oczekiwaniom przedsiębiorcy, ponieważ zmieniając pracę, przenosi wiedzę i zdobyte umiejętności do innej, często konkurencyjnej firmy. W warunkach kultury europejskiej pracownik ten jest oceniany jako mniej uczciwy oraz mniej lojalny wobec firmy. Natomiast w warunkach kultury amerykańskiej odchodzący z firmy pracownik ma szanse rozwijania współpracy między poprzednią a obecną firmą. Wpływa to na jego możliwości dalszego doskonalenia i awansu zawodowego, jak również stwarza możliwości rozwijania wzajemnej współpracy między obiema firmami. Przyjmuje się bowiem, że wcześniejsza znajomość firmy przez odchodzącego pracownika daje większe możliwości podejmowania i rozwijania współpracy między jego dawnym a nowym miejscem pracy.

Problematyka edukacji w zakresie przedsiębiorczości winna nawiązywać także do idei tworzenia wspólnoty europejskiej, którą w mniejszym stopniu da się budować na zasadach ekonomii czy polityki zagranicznej, a w większym stopniu na fundamencie wspólnego dzieła oraz wspólnych wartości kulturowych. Żyjemy bowiem w okresie nasilających się konfrontacji

Tab. 1. Poszukiwane cechy absolwentów przez przedsiębiorców (w pkt.)

\begin{tabular}{|l|c|c|}
\hline \multicolumn{1}{|c|}{ Cechy } & $\begin{array}{c}\text { Potrzeby } \\
\text { przedsiębiorstwa }\end{array}$ & $\begin{array}{c}\text { Realizacja przez } \\
\text { uczelnie }\end{array}$ \\
\hline Uczciwość, wysoki poziom etyczny & 72 & 36 \\
\hline Lojalność wobec firmy & 72 & 27 \\
\hline Podejmowanie nowych zadań & 72 & 45 \\
\hline Odpowiedzialność & 68 & 35 \\
\hline Szacunek dla innych & 67 & 40 \\
\hline Dzialenie się wiedzą & 63 & 31 \\
\hline Elastyczność czasowa & 62 & 26 \\
\hline Otwartość na problemy innych & 52 & 28 \\
\hline Mobilność & 47 & 34 \\
\hline Koleżeńskość & 45 & 45 \\
\hline Konkurowanie z innymi & 25 & 43 \\
\hline
\end{tabular}

Źródło: Zachariasz 2011. 
różnych kultur, które w istotnym stopniu wpływają na zachowania jednostek, społeczeństw oraz organizacji i różnych form działalności gospodarczej (Koneczny 1935, Huntington 2008).

Należy przyjąć, że kształtowanie człowieka innowacyjnego o postawach przedsiębiorczych jest zadaniem niezwykle trudnym, ale koniecznym, które trzeba podjąć, jeżeli chcemy być narodem liczącym się wśród liderów postępu technologicznego, technicznego, ekonomicznego, społecznego, kulturowego czy politycznego. Podstawowym czynnikiem naszego powodzenia jest rozwijanie kreatywności i zwiększania współpracy instytucji edukacyjnych w pozostałych sektorach gospodarczych w zakresie dostosowania kierunków kształcenia do zmieniających się potrzeb rynku pracy oraz rozwijania systemu kształcenia ustawicznego w całym okresie pracy zawodowej. Działania te warunkują podnoszenia innowacyjności gospodarki i konkurencyjności oferowanych produktów na rynku, stwarzanie nowych miejsc pracy i ograniczanie odpływu za graniczę najwyżej kwalifikowanych kadr pracowniczych.

Zmiana sposobu myślenia o roli edukacji w zakresie przygotowania człowieka do przyjmowania postaw przedsiębiorczych wymaga wielu zabiegów, a zarysowana koncepcja miejsca przedsiębiorczości w edukacji nie będzie miała łatwej drogi realizacji. Pewną barierą może być przekonanie nauczycieli poszczególnych przedmiotów do tego, aby w przekazywanych treściach nawiązywali do kształtowania człowieka innowacyjnego, o postawach przedsiębiorczych, który rozumie procesy rozwoju cywilizacyjnego i potrafi w sposób racjonalny szukać dla siebie odpowiedniego miejsca w zmieniającym się świecie. Barierą mogą być także media, dla których kryterium programowym nie jest kształtowanie wspomnianych postaw, ale proponowanie odbiorcom taniej rozrywki niewymagającej większego wysiłku intelektualnego. Wyrazem tego są między innymi wielkie widowiska tworzące ze zbiorowości jednostek ludzkich bezkrytyczną masę fanów lub kibiców. Również nie wszystkie rodziny są w stanie zrozumieć i przyjąć proponowane wzorce oraz stwarzać możliwości kształtowania w swoim zakresie przedstawicieli przyszłych elit, niezbędnych dla rozwoju kraju, regionu czy poszczególnych sektorów gospodarki.

Procesy edukacyjne w większym zakresie winny kształtować i odpowiednio przygotowywać młodych ludzi do rozumienia współczesnych i przyszłych tendencji rozwoju cywilizacyjnego. W nawiązaniu do nich należy stwarzać możliwości pobudzania coraz wyższych aspiracji i układania coraz ambitniejszych planów życiowych, które pozwolą na opanowanie umiejętności poszukiwania swojego miejsca w działalności gospodarczej, społecznej, kulturowej czy politycznej. Przyczyni się to do kształtowania racjonalnych struktur społecznych umożliwiających wzrost zasobów intelektualnych, które umożliwią budowanie kapitału ludzkiego i społecznego (Borowiec 2007; Kamińska, Heffner 2010; Zioło 2010). Dlatego można przyjąć tezę, że drogą do sukcesu indywidualnego i społecznego w zakresie kreowania nowoczesnej bazy ekonomicznej gospodarki opartej na wiedzy jest dobrze przemyślane i zorganizowane kształcenie, dokształcanie i doskonalenie zawodowe, które będzie zmierzać do wykreowania człowieka innowacyjnego o odpowiednio wykształconych cechach przedsiębiorczych. Możliwości rozwoju społecznego, gospodarczego, kulturowego oraz kreowanie racjonalnej polityki stwarzają bowiem tylko odpowiednio przygotowani ludzie, rozumiejący współczesne procesy i przyszłe tendencje przemian nawiązujące do nowych wyzwań cywilizacji społeczeństwa informacyjnego. 


\section{Literatura}

1. Adamczyk C., Fandrejewska A., 2012, Rekordowa wartość długu rządów do spłacenia, „Rzeczpospolita" z 2 stycznia.

2. Błażejewski M., 2006, Problemy rozwoju postaw przedsiębiorczości u gimnazjalistów [w:] Rola przedsiębiorczości w podnoszeniu konkurencyjności społeczeństwa i gospodarki, Z. Zioło, T. Rachwał (red.), „Przedsiębiorczość - Edukacja”, nr 2, wydawnictwo Nowa Era, Zakład Przedsiębiorczości i Gospodarki Przestrzennej Instytutu Geografii Akademii Pedagogicznej im. Komisji Edukacji Narodowej w Krakowie, Warszawa - Kraków, s. 249-255.

3. Borowiec M., 2007, Rola szkolnictwa wyższego w podnoszeniu jakości kapitalu ludzkiego [w:] Rola przedsiębiorczości w aktywizacji gospodarczej, Z. Zioło, T. Rachwał (red.), „Przedsiębiorczość - Edukacja”, nr 3, wydawnictwo Nowa Era, Zakład Przedsiębiorczości i Gospodarki Przestrzennej Akademii Pedagogicznej im. Komisji Edukacji Narodowej w Krakowie, Warszawa - Kraków, s. $142-150$.

4. Borowiec M., 2008, Rola szkolnictwa wyższego w procesie ksztaltowania gospodarki opartej na wiedzy [w:] Rola przedsiębiorczości w gospodarce opartej na wiedzy, Z. Zioło, T. Rachwał (red.), „Przedsiębiorczość - Edukacja”, nr 4, wydawnictwo Nowa Era, Zakład Przedsiębiorczości i Gospodarki Przestrzennej Instytutu Geografii Uniwersytetu Pedagogicznego im. Komisji Edukacji Narodowej w Krakowie, Warszawa - Kraków, s. 24-36.

5. Borowiec M., 2009, Rola edukacji w kształtowaniu społeczeństwa informacyjnego [w:] Rola przedsiębiorczości w kształtowaniu społeczeństwa informacyjnego, Z. Zioło, T. Rachwał (red.), „Przedsiębiorczość - Edukacja”, nr 5, wydawnictwo Nowa Era, Zakład Przedsiębiorczości i Gospodarki Przestrzennej Instytutu Geografii Uniwersytetu Pedagogicznego im. Komisji Edukacji Narodowej w Krakowie, Warszawa - Kraków, s. 37-47.

6. Borowiec M., 2011, Rola edukacji w procesach globalizacji [w:] Przedsiębiorczość w warunkach globalizacji, Z. Zioło, T. Rachwał (red.), „Przedsiębiorczość - Edukacja”, nr 7, wydawnictwo Nowa Era, Zakład Przedsiębiorczości i Gospodarki Przestrzennej Instytutu Geografii Uniwersytetu Pedagogicznego im. Komisji Edukacji Narodowej w Krakowie, Warszawa - Kraków, s. 296-307.

7. Borowiec M., Rachwał T., 2011, Ksztaltowanie postaw przedsiębiorczych na lekcjach geografii wyzwaniem edukacyjnym w procesach globalizacji [w:] Przedsiębiorczość $w$ warunkach globalizacji, Z. Zioło, T. Rachwał (red.), „Przedsiębiorczość - Edukacja”, nr 7, wydawnictwo Nowa Era, Zakład Przedsiębiorczości i Gospodarki Przestrzennej Instytutu Geografii Uniwersytetu Pedagogicznego im. Komisji Edukacji Narodowej w Krakowie, Warszawa - Kraków, s. 321-332.

8. Cieśliński P., 2011, Sceny z życia patrioty, którego uznano za zdrajcę, „Gazeta Wyborcza” z 15 lipca.

9. Czapliński P., 2006, Postawy uczniów ponadpodstawowych szkół ogólnoksztatcacych wobec rynku pracy [w:] Rola przedsiębiorczości w podnoszeniu konkurencyjności spoteczeństwa i gospodarki, Z. Zioło, T. Rachwał (red.), „Przedsiębiorczość - Edukacja”, nr 2, wydawnictwo Nowa Era, Zakład Przedsiębiorczości i Gospodarki Przestrzennej Instytutu Geografii Akademii Pedagogicznej im. Komisji Edukacji Narodowej w Krakowie, Warszawa - Kraków, s. 236-241.

10. Czeladko R., 2011a, Licealiści: nauki ścisłe daja pracę, „Rzeczpospolita” z 16 października.

11. Czeladko R., 2011b, Studia ściste i techniczne nadal będa promowane, „Rzeczpospolita” z 5 grudnia.

12. Desperak J., Depczyńska A., 2007, Przedsiębiorczy uczeń w UE-propozycje tematów lekcji [w:] Rola przedsiębiorczości w aktywizacji gospodarczej, Z. Zioło, T. Rachwał (red.), „Przedsiębiorczość Edukacja”, nr 3, wydawnictwo Nowa Era, Zakład Przedsiębiorczości i Gospodarki Przestrzennej Akademii Pedagogicznej im. Komisji Edukacji Narodowej w Krakowie, Warszawa - Kraków, s. $325-331$.

13. Dorocki S., Kilar W., Rachwał T., 2011, Założenia i cele Projektu „Krok w przedsiębiorczość” dla nauczycieli szkót ponadgimnazjalnych [w:] Przedsiębiorczość w warunkach globalizacji, Z. Zioło, T. Rachwał (red.), „Przedsiębiorczość - Edukacja”, nr 7, wydawnictwo Nowa Era, Zakład Przedsiębiorczości i Gospodarki Przestrzennej Instytutu Geografii Uniwersytetu Pedagogicznego im. Komisji Edukacji Narodowej w Krakowie, Warszawa - Kraków, s. 308-320. 
14. Gierańczyk W., 2009, Rozwój społeczeństwa informacyjnego a przedsiębiorczość w krajach transformujacych się [w:] Rola przedsiębiorczości w ksztaltowaniu spoleczeństwa informacyjnego, Z. Zioło, T. Rachwał (red.), „Przedsiębiorczość - Edukacja”, nr 5, wydawnictwo Nowa Era, Zakład Przedsiębiorczości i Gospodarki Przestrzennej Instytutu Geografii Uniwersytetu Pedagogicznego im. Komisji Edukacji Narodowej w Krakowie, Warszawa - Kraków, s. 19-36.

15. Grodzicki J., 2000, Edukacja czynnikiem rozwoju gospodarczego, Wydawnictwo A. Marszałek, Toruń.

16. Główny Urząd Statystyczny, 2011, Rocznik statystyczny Rzeczypospolitej Polskiej 2011, Warszawa.

17. Harańczyk A., 2008, Potencjat rozwojowy szkól Małopolski [w:] Rola przedsiębiorczości w gospodarce opartej na wiedzy, Z. Zioło, T. Rachwał (red.), „Przedsiębiorczość - Edukacja”, nr 4, wydawnictwo Nowa Era, Zakład Przedsiębiorczości i Gospodarki Przestrzennej Instytutu Geografii Uniwersytetu Pedagogicznego im. Komisji Edukacji Narodowej w Krakowie, Warszawa - Kraków, s. 37-59.

18. Huntington S.P., 2008, Zderzenie cywilizacji, Warszawskie Wydawnictwo Literackie MUZA SA, Warszawa.

19. Kamińska W., Heffner K., (red.), 2010, Kapitał ludzki i społeczny w procesie rozwoju obszarów wiejskich, „Studia KPZR PAN”, t. CXXVI.

20. Kawecki Z., 2005, Ranga przedmiotu podstawy przedsiębiorczości w edukacji szkolnej [w:] Przedsiębiorczość a współczesne wyzwania cywilizacyjne, Z. Zioło, T. Rachwał (red.), „Przedsiębiorczość - Edukacja”, nr 1, Zakład Przedsiębiorczości i Gospodarki Przestrzennej Instytutu Geografii Akademii Pedagogicznej im. Komisji Edukacji Narodowej w Krakowie, Wydawnictwo „MiWa”, Kraków, s. 203-206.

21. Kilar W., 2007, Zagadnienie globalizacji i korporacji ponadnarodowych w edukacji przedsiębiorczości [w:] Rola przedsiębiorczości w aktywizacji gospodarczej, Z. Zioło, T. Rachwał (red.), „Przedsiębiorczość - Edukacja”, nr 3, wydawnictwo Nowa Era, Zakład Przedsiębiorczości i Gospodarki Przestrzennej Akademii Pedagogicznej im. Komisji Edukacji Narodowej w Krakowie, Warszawa Kraków, s. 297-304.

22. Kilar W., 2009, Rola korporacji Apple w ksztaltowaniu spoleczeństwa informacyjnego [w:] Rola przedsiębiorczości w ksztaltowaniu społeczeństwa informacyjnego, Z. Zioło, T. Rachwał (red.), „Przedsiębiorczość - Edukacja”, nr 5, wydawnictwo Nowa Era, Zakład Przedsiębiorczości i Gospodarki Przestrzennej Instytutu Geografii Uniwersytetu Pedagogicznego im. Komisji Edukacji Narodowej w Krakowie, Warszawa - Kraków, s. 48-56.

23. Koneczny F., 1935, O wielości cywilizacji, Wyd. Gebether Wolff, Kraków; Reprint, Wyd. Antyk, Komorów 1998.

24. Majewska J., 2006, Wyzwalanie ducha przedsiębiorczości w środowisku społecznym gminy dla rozwoju lokalnego [w:] Rola przedsiębiorczości w podnoszeniu konkurencyjności spoleczeństwa i gospodarki, Z. Zioło, T. Rachwał (red.), „Przedsiębiorczość - Edukacja”, nr 2, wydawnictwo Nowa Era, Zakład Przedsiębiorczości i Gospodarki Przestrzennej Instytutu Geografii Akademii Pedagogicznej im. Komisji Edukacji Narodowej w Krakowie, Warszawa - Kraków, s. 91-100.

25. Makieła B., Makieła Z., 2005, Nauczanie podstaw przedsiębiorczości w liceach ogólnokształcacych i liceach profilowanych [w:] Przedsiębiorczość a wspótczesne wyzwania cywilizacyjne, Z. Zioło, T. Rachwał (red.), „Przedsiębiorczość - Edukacja”, nr 1, Zakład Przedsiębiorczości i Gospodarki Przestrzennej Instytutu Geografii Akademii Pedagogicznej im. Komisji Edukacji Narodowej w Krakowie, Wydawnictwo „MiWa”, Kraków, s. 177-188.

26. Mitura E., Jamroz D., 2005, Przedsiębiorczy uczeń na rynku pracy [w:] Przedsiębiorczość a wspótczesne wyzwania cywilizacyjne, Z. Zioło, T. Rachwał (red.), „Przedsiębiorczość - Edukacja”, nr 1, Zakład Przedsiębiorczości i Gospodarki Przestrzennej Instytutu Geografii Akademii Pedagogicznej im. Komisji Edukacji Narodowej w Krakowie, Wydawnictwo „MiWa”, Kraków, s. 277-296.

27. Nowak K., 2007, Start młodzieży na rynku pracy [w:] Rola przedsiębiorczości w aktywizacji gospodarczej, Z. Zioło, T. Rachwał (red.), „Przedsiębiorczość - Edukacja”, nr 3, wydawnictwo Nowa Era, Zakład Przedsiębiorczości i Gospodarki Przestrzennej Akademii Pedagogicznej im. Komisji Edukacji Narodowej w Krakowie, Warszawa - Kraków, s. 172-179. 
28. Osuch W., 2011, Kompetencje w zakresie komunikacji interpersonalnej $w$ dobie postępujacych procesów globalizacji [w:] Przedsiębiorczość w warunkach globalizacji, Z. Zioło, T. Rachwał (red.), „Przedsiębiorczość - Edukacja”, nr 7, wydawnictwo Nowa Era, Zakład Przedsiębiorczości i Gospodarki Przestrzennej Instytutu Geografii Uniwersytetu Pedagogicznego im. Komisji Edukacji Narodowej w Krakowie, Warszawa - Kraków, s. 333-346.

29. Piróg D., 2005, Miejsce i rola edukacji europejskiej w nauczaniu podstaw przedsiębiorczości w kontekście współczesnych wyzwań cywilizacyjnych [w:] Przedsiębiorczość a współczesne wyzwania cywilizacyjne, Z. Zioło, T. Rachwał (red.), „Przedsiębiorczość - Edukacja”, nr 1, Zakład Przedsiębiorczości i Gospodarki Przestrzennej Instytutu Geografii Akademii Pedagogicznej im. Komisji Edukacji Narodowej w Krakowie, Wydawnictwo „MiWa”, Kraków, s. 213-220.

30. Piróg D., 2010, Studia wyższe a rynek pracy w Polsce - zarys stanu badań [w:] Studia wyższe z perspektywy rynku pracy, B. Sitarska, K. Jankowski, R. Droba (red.), Wydawnictwo Akademii Podlaskiej, Siedlce, s. 67-80.

31. Polscy uczniowie znaleźli dwie nieznane wcześniej planetoidy, 2011, „Gazeta Wyborcza. Technologie" z dnia 9 maja.

32. Rachwał T., 2005, Kształtowanie postaw uczniów na lekcjach podstaw przedsiębiorczości [w:] Przedsiębiorczość a wspótczesne wyzwania cywilizacyjne, Z. Zioło, T. Rachwał (red.), „Przedsiębiorczość - Edukacja”, nr 1, Zakład Przedsiębiorczości i Gospodarki Przestrzennej Instytutu Geografii Akademii Pedagogicznej im. Komisji Edukacji Narodowej w Krakowie, Wydawnictwo „MiWa”, Kraków, s. 137-144.

33. Rachwał T., Kudełko J., Tracz M., Wach K., Kilar W., 2008, Projekt podstawy programowej podstaw przedsiębiorczości $w$ zakresie rozszerzonym dla liceum ogólnokształcącego, liceum profilowanego i technikum [w:] Rola przedsiębiorczości w gospodarce opartej na wiedzy, Z. Zioło, T. Rachwał (red.), „Przedsiębiorczość - Edukacja”, nr 4, wydawnictwo Nowa Era, Zakład Przedsiębiorczości i Gospodarki Przestrzennej Instytutu Geografii Uniwersytetu Pedagogicznego im. Komisji Edukacji Narodowej w Krakowie, Warszawa - Kraków, s. 312-324.

34. Rachwał T., 2009, Ocena projektu zmian postawy programowej podstaw przedsiębiorczości [w:] Rola przedsiębiorczości w ksztattowaniu społeczeństwa informacyjnego, Z. Zioło, T. Rachwał (red.), „Przedsiębiorczość - Edukacja”, nr 5, wydawnictwo Nowa Era, Zakład Przedsiębiorczości i Gospodarki Przestrzennej Instytutu Geografii Uniwersytetu Pedagogicznego im. Komisji Edukacji Narodowej w Krakowie, Warszawa - Kraków, s. 349-373.

35. Robot studentów z AGH bezkonkurencyjny, 2011, „Gazeta Wyborcza” z dnia 29 marca.

36. Rosiak J., Szczypa P., 2007, Proekologiczna edukacja $w$ kształtowaniu podstaw przedsiębiorczości [w:] Rola przedsiębiorczości w aktywizacji gospodarczej, Z. Zioło, T. Rachwał (red.), „Przedsiębiorczość - Edukacja”, nr 3, wydawnictwo Nowa Era, Zakład Przedsiębiorczości i Gospodarki Przestrzennej Akademii Pedagogicznej im. Komisji Edukacji Narodowej w Krakowie, Warszawa - Kraków, s. 332-336.

37. Rybak A., 2011, Metoda profesora Czochralskiego, „Rzeczpospolita. PlusMinus” z 16-17 lipca.

38. Sowislok K., 2007, Zachowanie młodzieży na współczesnym rynku pracy [w:] Rola przedsiębiorczości w aktywizacji gospodarczej, Z. Zioło, T. Rachwał (red.), „Przedsiębiorczość - Edukacja”, nr 3, wydawnictwo Nowa Era, Zakład Przedsiębiorczości i Gospodarki Przestrzennej Akademii Pedagogicznej im. Komisji Edukacji Narodowej w Krakowie, Warszawa - Kraków, s. 162-171.

39. Suchy J.S., 2011, Potrzeba wyksztatconych inżynierów, „Rzeczpospolita” z 29 czerwca.

40. Szczepański J., 1973, Refleksje nad oświata, PIW, Warszawa.

41. Tracz M., 2006, Rola i znaczenie podstaw przedsiębiorczości w kształceniu ogólnym [w:] Rola przedsiębiorczości w podnoszeniu konkurencyjności społeczeństwa i gospodarki, Z. Zioło, T. Rachwał (red.), „Przedsiębiorczość - Edukacja”, nr 2, wydawnictwo Nowa Era, Zakład Przedsiębiorczości i Gospodarki Przestrzennej Instytutu Geografii Akademii Pedagogicznej im. Komisji Edukacji Narodowej w Krakowie, Warszawa - Kraków, s. 222-225.

42. Tracz M., Rachwał T., 2007, Przedmiot podstawy przedsiębiorczości-założenia realizacji a przygotowanie nauczycieli [w:] Rola przedsiębiorczości w aktywizacji gospodarczej, Z. Zioło, T. Rachwał (red.), „Przedsiębiorczość - Edukacja”, nr 3, wydawnictwo Nowa Era, Zakład Przedsiębiorczości i Gospodarki Przestrzennej Akademii Pedagogicznej im. Komisji Edukacji Narodowej w Krakowie, Warszawa - Kraków, s. 286-296. 
43. Tracz M., Rachwał T., 2008, Metody nauczania i środki dydaktyczne stosowane przez nauczycieli podstaw przedsiębiorczości - wyniki badań [w:] Rola przedsiębiorczości w gospodarce opartej na wiedzy, Z. Zioło, T. Rachwał (red.), „Przedsiębiorczość - Edukacja”, nr 4, wydawnictwo Nowa Era, Zakład Przedsiębiorczości i Gospodarki Przestrzennej Instytutu Geografii Uniwersytetu Pedagogicznego im. Komisji Edukacji Narodowej w Krakowie, Warszawa - Kraków, s. 324-330.

44. Turczyn-Zioło I., 1979, Aspiracje i plany życiowe młodzieży szkót ponadpodstawowych obszaru uprzemysławianego i rolniczego (na przykładzie województwa tarnobrzeskiego), „Zeszyty Badań Rejonów Uprzemysławianych KBRU PAN", z. 72, s. 5-141.

45. Turczyn-Zioło I., 1983, Przemiany sieci szkolnictwa $w$ województwie tarnobrzeskim pod wpływem procesów industrializacji $w$ latach 1960-1980, „Zeszyty Badań Rejonów Uprzemysławianych KBRU PAN", z. 77, s. 187-262.

46. Wąsik H., 2010, Nauczanie przedsiębiorczości w kontekście integracji europejskiej [w:] Przedsiębiorczość w warunkach integracji europejskiej, Z. Zioło, T. Rachwał (red.), „Przedsiębiorczość Edukacja”, nr 6, wydawnictwo Nowa Era, Zakład Przedsiębiorczości i Gospodarki Przestrzennej Instytutu Geografii Uniwersytetu Pedagogicznego im. Komisji Edukacji Narodowej w Krakowie, Warszawa - Kraków, s. 486-492.

47. Zachariasz K., 2011, Pracodawcy nie chca wyścigu szczurów, „Gazeta Wyborcza” z dnia 27 września. 48. Zioło I., 1984, Kto na studia?, „Przegląd Techniczny”, nr 46.

49. Zioło I., 1999, Wybrane atrybuty wartości edukacyjnej wyższej szkoły niepaństwowej (wyniki badań sondażowych prowadzonych w WSIiZ w Rzeszowie) [w:] Problemy przemian układów regionalnych, cz. II, Z. Zioło (red.), „Zeszyty Naukowe Wyższej Szkoły Informatyki i Zarządzania w Rzeszowie”, nr 3, Rzeszów, s. 97-122.

50. Zioło Z., 2010, Rola zasobów intelektualnych, kapitału ludzkiego i społecznego w procesach rozwoju obszarów wiejskich [w:] Kapitat ludzki i społeczny w procesie rozwoju obszarów wiejskich, W. Kamińska, K. Heffner (red.), „Studia KPZR PAN”, t. CXXVI, s. 9-28.

51. Zioło Z., Rachwał T. (red.), 2005, Przedsiębiorczość a współczesne wyzwania cywilizacyjne, „Przedsiębiorczość - Edukacja”, nr 1, Zakład Przedsiębiorczości i Gospodarki Przestrzennej Instytutu Geografii Akademii Pedagogicznej im. Komisji Edukacji Narodowej w Krakowie, Wydawnictwo „MiWa”, Kraków.

52. Zioło Z., Rachwał T. (red.), 2006, Rola przedsiębiorczości w podnoszeniu konkurencyjności społeczeństwa i gospodarki, „Przedsiębiorczość - Edukacja”, nr 2, wydawnictwo Nowa Era, Zakład Przedsiębiorczości i Gospodarki Przestrzennej Instytutu Geografii Akademii Pedagogicznej im. Komisji Edukacji Narodowej w Krakowie, Warszawa - Kraków.

53. Zioło Z., Rachwał T. (red.), 2007, Rola przedsiębiorczości w aktywizacji gospodarczej, „Przedsiębiorczość - Edukacja”, nr 3, wydawnictwo Nowa Era, Zakład Przedsiębiorczości i Gospodarki Przestrzennej Akademii Pedagogicznej im. Komisji Edukacji Narodowej w Krakowie, Warszawa - Kraków.

54. Zioło Z., Rachwał T. (red.), 2008, Rola przedsiębiorczości w gospodarce opartej na wiedzy, „Przedsiębiorczość - Edukacja”, nr 4, wydawnictwo Nowa Era, Zakład Przedsiębiorczości i Gospodarki Przestrzennej Instytutu Geografii Uniwersytetu Pedagogicznego im. Komisji Edukacji Narodowej w Krakowie, Warszawa - Kraków.

55. Zioło Z., Rachwał T. (red.), 2009, Rola przedsiębiorczości w kształtowaniu społeczeństwa informacyjnego, „Przedsiębiorczość - Edukacja”, nr 5, wydawnictwo Nowa Era, Zakład Przedsiębiorczości i Gospodarki Przestrzennej Instytutu Geografii Uniwersytetu Pedagogicznego im. Komisji Edukacji Narodowej w Krakowie, Warszawa - Kraków.

56. Zioło Z., Rachwał T. (red.), 2010, Przedsiębiorczość w warunkach integracji europejskiej, „Przedsiębiorczość - Edukacja”, nr 6, wydawnictwo Nowa Era, Zakład Przedsiębiorczości i Gospodarki Przestrzennej Instytutu Geografii Uniwersytetu Pedagogicznego im. Komisji Edukacji Narodowej w Krakowie, Warszawa - Kraków.

57. Zioło Z., Rachwał T. (red.), 2011, Przedsiębiorczość w warunkach globalizacji, „Przedsiębiorczość - Edukacja”, nr 7, wydawnictwo Nowa Era, Zakład Przedsiębiorczości i Gospodarki Przestrzennej Instytutu Geografii Uniwersytetu Pedagogicznego im. Komisji Edukacji Narodowej w Krakowie, Warszawa - Kraków. 


\section{A place of entrepreneurship in education}

In times of building the information society, quality and standards of education are the primary factors of the social, economic and cultural development. The paper discusses the problematic aspects of studies on educational role in entrepreneurship development with reference to this idea and additionally the premise to shape entrepreneurial attitudes when teaching in postsecondary schools. Given the above it outlines expectations of the labour markets towards new employees. 